\title{
Pengembangan Permainan Harta Karun Si Bola-Bola dalam Pembelajaran Sosial Emosional Anak Usia 5-6 Tahun di Taman Kanak-Kanak
}

\author{
Rahma Putri Wina, Tomas Iriyanto, Eny Nur Aisyah \\ Program Studi di PG-PAUD, Fakultas Ilmu Pendidikan, Universitas Malang. \\ Jalan Semarang no. 5 Malang, Universitas Malang, Indonesia \\ E-mail: loveowl29@gmail.com, tomas.iriyanto.fip@um.ac.id, eny.nur.fip@um.ac.id
}

\begin{tabular}{ll}
\hline \hline ARTICLE INFO & ABSTRACT \\
\hline \hline Article history: & Penelitian ini menghasilkan produk permainan harta karun si bola-bola yang \\
Received: $9-12-2019$ & aman, mudah dan menarik serta sebagai inovasi untuk meningkatkan \\
Revised: $16-12-2019$ & perkembangan sosial emosional. Tujuan penelitian ini untuk menghasilkan \\
Accepted: $23-12-2019$ & permainan yang dapat membantu meningkatkan perkembangan aspek sosial \\
& emosional anak usia 5-6 tahun. Penelitian ini menggunakan rancangan penelitian \\
Keywords: & dan pengembangan dari Borg and Gall. Model ini memiliki 10 langkah \\
Game, treasure, & penelitian, namun karena keterbatasan peneliti, maka menggunakan 7 langkah, \\
social emotional & penelitian ini dilakukan di 5 TK dengan subjek 76 anak. Data kualitatif diperoleh \\
learning. & dari wawancara dan data evaluasi dari para ahli, sedangkan data kuantitatif \\
& diperoleh dari data permainan yaitu aspek keamanan, kemudahan, dan \\
& kemenarikan digunakan untuk meningkatkan perkembangan sosial emosional \\
anak usia 5-6 tahun.
\end{tabular}

\section{PENDAHULUAN}

Anak usia dini berada pada tahap masa golden age, dimana masa tersebut sangat penting untuk mengembangkan berbagai aspek perkembangan yang dimiliki oleh anak dengan memberikan stimulus yang tepat. Perkembangan sosial emosional anak usia dini merupakan salah satu perkembangan yang penting bagi anak, karena anak hidup mengikuti lingkungan kedua orang tuanya atau pun keluarganya di lingkungan masyarakat. Perlu adanya stimulasi untuk mengembangkan aspek sosial emosinal anak yang nantinya dapat mempengaruhi aspek perkembangan lainnya. Lingkungan sosial anak setelah keluarga adalah lingkungan di sekolah, anak bermain dengan teman sebayanya adalah bentuk sosialisasi anak terhadap lingkungan sekolah. Wiyani (2014: 20-21) mejelaskan bahwa perkembangan sosial anak usia dini dapat didefinisikan dengan berbagai perubahan terkait dengan kemampuan anak usia 0-6 tahun dalam menjalin relasi dengan dirinya sendiri maupun dengan orang lain untuk mendapatkan keinginannya.

Perkembangan sosial anak ini mulai sedikit komplek ketika anak menginjak usia 4 tahun dimana anak mulai memasuki ranah pendidikan yang paling dasar yaitu taman kanak-kanak (Rahman,2002). Anak usia 4-6 tahun perkembangan sosial sudah mulai berjalan. Hal ini tampak dari kemampuan mereka dalam melakukan kegiatan secara berkelompok. Kegiatan bersama berbentuk seperti sebuah permainan. Dari sisi sosial emosional, kegiatan bermain dalam melatih anak dalam 
memahami perasaan teman lainnya. Konflik dalam interaksi keduanya akan membantu anak dalam memahami bahwa orang selain dirinya yaitu temannya memiliki cara pandang yang berbeda dari dirinya. Mengembangkan kemampuan anak dengan cara yang menyenangkan bagi anak melalui kegiatan bermain. Bermain adalah suatu aktivitas berkaitan erat dengan dunia anak, dengan bermain anak merasakan kesenangan dan dengan bermain anak dapat melampiaskan energi yang dimilikinya dengan sebuah kegiatan yang menyenangkan. Menurut Elkind (dalam Pramono, 2015: 25) bermain merupakan sebagai suatu kegiatan pelepasan atau pembebasan terhadap tekanan-tekanan yang dihadapi anak-anak. Sedangkan menurut Athey 1984 \& Hendrick 1986 (dalam Pramono, 2015: 25) bermain memberi anak-anak kesempatan untuk menguji tubuhnya, melihat seberapa baik anggota tubuhnya berfungsi, bermain membantu mereka merasa percaya diri secara fisik, merasa aman, dan mempunyai keyakinan diri.

Berdasarkan paparan pendapat ahli di atas bermain merupakan suatu kegiatan pelepasan atau bentuk pembebasan tekanan-tekanan yang dihadapi anak dalam kehidupan sehari-hari dengan melakukan aktivitas berupa berimajinasi dan menggerakan anggota tubuh yang dilakukan dengan perasaan senang. bermain juga dapat memunculkan perasaan percaya diri, rasa aman serta memiliki keyakian diri. Melakukan sebuah aktivitas bermain perlu adanya sarana yang mampu menunjang kegiatan bermain tersebut, sarana tersebut adalah permainan. Permainan merupakan suatu kegiatan yang dapat membuat anak merasa senang dengan pengelolaan aktivitas bermain. Permainan berperan penting bagi kemampuan anak karena dapat mengembangkan berbagai macam aspek perkembangan anak jika permainan tersebut dirancang sesuai dengan kebutuhan pertumbuhan anak. Menurut Santrock (2007: 216) permainan adalah suatu kegiatan yang menyenangkan, kegiatan tersebut dilakukan untuk kepentingan kegiatan itu sendiri dan dilakukan dengan perasaan senang. Masgumelar, dkk (2017: 156) menyatakan bahwa permainan adalah aktivitas yang dominan pada masa kanakkanak dimana anak dapat memperoleh ketrampilan baru dan aktivitas tersebut dibatasi dengan aturanaturan yang disepakati.

Berdasarkan paparan pendapat di atas dapat diambil kesimpulan bahwa permainan merupakan suatu kegiatan yang menyenangkan dan dapat membuat anak merasa senang, kegiatan tersebut dilakukan tanpa adanya paksaan. Anak dapat memperoleh keterampilan maupun kemampuan baru ketika anak bermain suatu permainan dan terdapat aturan-aturan yang disepakati dalam sebuah permainan, aturan tersebut digunakan agar permainan tersebut dapat dimainkan oleh anak. Fakta yang terjadi di lapangan, jarangnya penggunaan permainan berkelompok pada lembaga pendidikan anak usia dini, anak masih banyak terfokuskan pada penggunaan lembar tugas siswa yang terus menerus, seringnya pembelajaran yang dilakukan di dalam kelas, meski ada beberapa permainan yang dapat dilakukan di dalam kelas anak membutuhkan ruang untuk bergerak bebas. Di luar kelas anak akan lebih leluasa untuk bergerak. Terdapat juga beberapa sekolah yang meniadakan jam istirahat untuk bermain di luar dan kurangnya lahan bermain bagi anak. Beberapa masalah ini dapat menjadi faktor yang mempengaruhi perkembangan anak terlebih perkembangan sosial dan emosional. Permendikbud no. 137 tahun 2014 tentang standar nasional pendidikan anak usia dini adapun tahapan perkembangan anak usia 5-6 tahun yaitu menyesuaikan diri, sifat percaya, mengelola perasaan diri, mengetahui haknya, mematuhi peraturan, bertanggung jawab, bermain, berbagi, menghargai, menyelesaikan masalah, kooperatif, toleran, mengekspresikan emosi, mengenal tata krama dan sopan santun. Peneliti melakukan observasi awal, saat kegiatan bermain menggunakan pola berkelompok terdapat 9 dari 20 anak yang belum mampu bekerja sama dalam bermain, tidak mau berbagi dengan teman dan anak mudah marah. Penggunaan alat permainan yang kurang menarik juga dapat menjadi faktor penyebab kurang tertariknya anak dengan permainan itu sehingga anak pun seenaknya sendiri dalam bermain. Beberapa anak yang perkembangan sosial emosional masih belum sesuai dengan tahapan perkembangan anak usia 5-6 tahun.

Sejalan dengan uraian tersebut, peneliti akan mengembangkan sebuah permainan untuk meningkatkan aspek perkembangan sosial emosional anak, melalui kegiatan bermain yang terarah dan menyenangkan, yaitu permainan harta karun si bola-bola. Permainan harta karun si bola-bola memiliki 6 zona yang harus diselesaikan oleh anak, dalam masing-masing zona terdapat permainan yang semua anak dapat bekerja sama berpartisipasi melakukan kegiatan permainan. Peneliti mencari beberapa sekolah untuk melaksanakan penelitian yang memiliki halaman luas untuk memaksimalkan pengembangan permainan. Diharapkan permainan harta karun yang berjudul harta karun si bola-bola menjadi sebuah aktivitas yang menyenangkan bagi anak untuk meningkatkan perkembangan sosial 
emosional anak usia 5-6 tahun yang belum terasah secara maksimal.

\section{METODE}

Penelitian ini menggunakan metode penelitian dan pengembangan atau dalam bahasa inggris disebut Research and Development (R\&D). Sugiyono (2016: 297) menyatakan bahwa metode penelitian dan pengembangan adalah metode penelitian yang digunakan untuk menghasilkan produk tertentu, serta menguji keefektifan produk tersebut. Penelitian ini dirancang untuk menghasilkan produk berupa permainan harta karun si bola-bola dalam pembelajaran sosial emosional anak usia 5-6 tahun di taman kanak-kanak. Model ini memiliki 10 langkah penelitian, namun karena keterbatasan peneliti, maka hanya dilakukan 7 langkah penelitian. Langkah-langkah yang digunakan dalam penelitian ini meliputi, 1) penelitian dan pengumpulan data, 2) perencanaan, 3) pengembangan format produk awal, 4) uji coba awal, 5) revisi produk, 6) uji coba lapangan, 7) revisi produk.

Prosedur penelitian dan pengembangan permainan dilaksanakan dengan langkah-langkah sebagai berikut: 1) Pengumpulan data di TK BSS UB, TK Al-Fadholi, TK Satelit, TK akademika dan TK Asyuhada, melakukan penelitian dan pengumpulan informasi melalui pengamatan langsung atau observasi di kelas kelompok B dan sekolah, kemudian mengetahui kebutuhan yang harus ditingkatkan pada anak usia 5-6 tahun, 2) Perencanaan, yaitu merumuskan tujuan penelitian dan pengembangan produk yang akan dihasilkan meliputi rancangan produk dan pengembangan produk, 3) Pengembangan produk awal, yaitu pengembangan produk awal berupa permainan dengan format yang telah direncanakan setelah dievaluasi ahli sosial emosional, dan ahli permainan, 4) Uji coba awal (uji coba kelompok kecil), dilakukan dengan uji coba kelompok kecil pada 1 sekolah dengan 8 anak usia 5-6 tahun. Sebelum uji coba kelompok awal dilaksanakan proses validasi oleh para ahli terlebih dahulu terhadap produk yang dikembangkan, hasil uji coba kelompok kecil dan validasi ahli digunakan sebagai bahan evaluasi dan revisi untuk produk yang akan dikembangkan, 5) Revisi hasil uji coba, dilakukan dengan merevisi produk awal berdasarkan hasil uji coba lapangan pertama (uji coba kelompok kecil) untuk selanjutnya melaksanakan uji lapangan utama sesuai dengan saran-saran dari hasil uji coba lapangan pertama, 6) Uji coba lapangan, dilakukan dengan uji coba kelompok besar yang melibatkan seluruh anak usia 5-6 tahun TK Satelit, TK Syuhada, TK Akademika, TK Al-Fadholi dan TK BSS UB, 7) Revisi produk, yaitu penyempurnaan produk hasil uji coba kelompok besar sehingga menjadi produk pengembangan permainan untuk pembelajaran sosial emosional anak yang dilakukan berdasarkan masukan dan hasil evaluasi pada uji coba kelompok besar.

Subjek data yang terlibat dalam pengambilan data untuk pengembangan ini adalah: 1) Subjek analisis kebutuhan, terdiri dari 1 guru kelompok B di TK Satelit, 1 guru kelompok B di TK Syuhada, 1 guru kelompok B di TK Akademika, 1 guru kelompok B di TK Al-Fadholi, dan 1 guru kelompok B di TK BSS UB, 2) Subjek evaluasi, terdiri dari 2 ahli permainan, dan 2 ahli pembelajaran sosial emosional anak usia dini, 3) Subjek uji coba kelompok kecil, terdiri dari 8 anak perwakilan anak kelompok B TK Satelit, 4) Subjek uji coba kelompok besar, terdiri dari anak usia 5-6 tahun di TK Satelit sebanyak 16 anak, TK Asyuhada 16 anak, TK Akademika 16 anak, TK Al-Fadholi 16 anak, dan TK BSS UB 12 anak, dengan total keseluruhan 76 anak.

Jenis data yang diperoleh merupakan data kualitatif dan kuantitatif, data kuantitatif diperoleh dari data hasil tinjauan para ahli yang berupa saran dan masukan, serta wawancara analisis kebutuhan. Selaras dengan itu data kuantitatif diperoleh dari data hasil validasi ahli, uji coba kelompok kecil dan uji coba lapangan berupa persentase keamanan, kemudahan dan kemenarikan. Instrumen pengumpulan data yang digunakan dalam penelitian dan pengembangan ini adalah menggunakan pendekatan kualitatif dan kuantitatif yang berupa kuesioner dan lembar observasi. Kuesioner ini digunakan untuk mengumpulkan data kuantitatif dari para ahli, lembar observasi digunakan untuk mengumpulkan data kuantitatif dari proses dan hasil saat permainan berlangsung dan data kualitatif diperoleh dari evaluasi ahli berupa saran dan masukan.

Teknik anlisis data yang digunakan di dalam pengembangan permainan adalah evaluasi para ahli untuk uji produk adalah data kualitatif dan data kuantitatif berupa porsentase, 1) Data kualitatif berupa saran dan masukan dari para ahli yang digunakan untuk melakukan revisi terhadap rancangan produk, 2) Data kuantitatif berupa presentase keamanan, kemudahan dan kemenarikan pada saat anak melakukan kegiatan bermain. Data tersebut digunakan untuk memporsentase hasil pengumpulan data pada penelitian awal (analisis kebutuhan), data uji coba kelompok kecil dan uji coba kelompok besar. Apabila datanya berupa porsentase, proporsi maupun rasio maka kesimpulan yang dapat diambil 
Rahma Putri Wina, Tomas Iriyanto, Eny Nur Aisyah

disesuaikan dengan permasalahannya. Berikut persentase keberhasilan validasi atau kelayakan menurut Akbar (2013: 41).

Tabel 1. Kriteria Kelayakan Permainan

\begin{tabular}{lll}
\hline o & \multicolumn{1}{c}{ Kriteria } & \multicolumn{1}{c}{ Tingkat Kelayakan } \\
\hline & $81,00 \%-100,00 \%$ & Sangat layak, atau dapat digunakan tanpa revisi. \\
& $61,00 \%-80,00 \%$ & Cukup Layak, atau dapat digunakan namun perlu direvisi kecil. \\
. & $41,00 \%-60,00 \%$ & Kurang layak, disarankan tidak dipergunakan karena perlu revisi besar. \\
& $21,00 \%-40,00 \%$ & Tidak layak, atau tidak boleh dipergunakan \\
& $00,00 \%-20,00 \%$ & Sangat tidak layak atau tidak boleh dipergunakan \\
\hline
\end{tabular}

Sumber: Akbar (2013: 42)

Permainan yang dikembangkan akan dikatakan berhasil dan dapat dimanfaatkan sebagai permainan untuk perkembangan sosial emosional apabila mencapai kriteria minimal $61.00 \%-80.00 \%$ (cukup layak).

\section{HASIL DAN PEMBAHASAN}

\section{Hasil}

Berdasarkan pengumpulan data dari penelitian dan pengembangan permainan harta karun si bola-bola untuk meningkatkan aspek perkembangan sosial emosional anak usia 5-6 tahun, di bawah ini akan disajikan data dari hasil tinjauan para ahli, uji coba kelompok kecil dan uji lapangan. Tinjauan para ahli digunakan sebagai dasar untuk melakukan revisi terhadap rancangan permainan yang telah dibuat. Tinjauan dari rancangan permainan tersebut dilakukan oleh empat orang ahli, yaitu dua ahli permainan dan dua ahli sosial emosional anak usia dini. Tujuan dari tinjauan para ahli adalah untuk mengetahui tingkat keamanan, kemudahan, dan kemenarikan permainan harta karun si bola-bola.

Tabel 2. Hasil Data Tinjauan Ahli

\begin{tabular}{lc}
\hline \multicolumn{1}{c}{ Hasil Kuesioner Ahli } & Persentase \\
\hline Hasil kuesioner ahli permainan AUD & $94,2 \%$ \\
Hasil kuesioner ahli sosial emosional AUD & $87,5 \%$ \\
\hline
\end{tabular}

Hasil tinjauan para ahli pada tabel di atas yang digunakan untuk mengetahui tingkat kelayakan permainan dari segi pendapat para ahli sekaligus untuk melakukan revisi dari rancangan permainan yang telah dibuat. Hasil evaluasi tinjauan para ahli permainan anak usia dini diperoleh hasil pesentase sebesar $94,2 \%$ dan saran dari ahli permainan yaitu lebih memperhatikan faktor keamanan anak, baik dari segi alat permainan yang dipakai maupun dari segi keamanan anak saat bermain. Hasil evaluasi tinjauan ahli sosial emosional anak usia dini diperoleh persentase sebesar 87,5\%, saran dan masukan dari ahli sosial emosional yaitu: 1) permainan harus memiliki rangkaian yang saling berhubungan antara satu permaianan dengan permainan yang lain sehingga permaianan tersebut terdapat tujuan yang dicapai anak ,2) tingkat kesulitan permainan (puzzle) harus sesuai dengan kriteria anak usia 5-6 tahun, 3) menjadikan permainan yang tidak monoton, 4) menambahkan buku petunjuk.

Tabel 3. Data Hasil Observasi Kegiatan Uji Coba

\begin{tabular}{|c|c|}
\hline $\begin{array}{rr}\text { Hasil Penelitian } \\
\end{array}$ & Persentase \\
\hline Hasil uji coba kelompok kecil & $86,8 \%$ \\
\hline Hasil uji lapangan & $94,8 \%$ \\
\hline
\end{tabular}

Uji coba kelompok kecil dilakukan di TK Satelit dengan subjek 8 anak usia 5-6 tahun. Hasil uji coba kelompok kecil diperoleh hasil sebesar $86,8 \%$. Selaras dengan itu, produk yang diuji coba pada lapangan awal (kelompok kecil) berada pada kriteria persentase sangat layak atau dapat digunakan tanpa revisi. Sedangkan uji coba lapangan memperoleh hasil 94,8\% dan tidak dilakukan revisi. Uji coba lapangan dilakukan di 5 lembaga TK yaitu TK Satelit, TK Syuhada, TK Akademika, TK Al- 
Fadholi dan TK BSS.

\section{Pembahasan}

Produk permainan harta karun si bola-bola telah melalui proses validasi dari ahli permainan anak usia dini dengan hasil $94,2 \%$. Apabila disetarakan dengan kriteria kelayakan permainan maka termasuk dalam persentase $81,00 \%-100,00 \%$ degan kualifikasi sangat layak, atau dapat digunakan tanpa revisi. Ahli permainan memberikan saran dan masukan dari ahli permainan yaitu lebih memperhatikan faktor keamanan anak, baik dari segi alat permainan yang dipakai maupun dari segi keamanan anak saat bermain. Sudono (2000:70-72) menyatakan kriteria pembuatan alat permainan yang harus diperhatikan seperti: kayu tidak berserat, bulu bambu yang gatal, tidak ada sisi yang tajam, cat non toxic (bebas racun), memasukkan benda berbahaya ke dalam mulut, memotong menggunakan pisau tajam (cutter), pembuatan dengan ukuran yang disesuaikan dengan anak, paku tidak boleh yang menonjol. Beberapa hal yang telah tercantum di atas sudah diperhatikan oleh peneliti dalam membuat alat permainan seperti memakai cat yang aman, kayu tidak berserat, setiap sisi tidak tajam dan tidak licin. Selaras dengan masukan tersebut alat permainan dan cara bermain anak pada permainan ini sudah berdasarkan pada kegiatan untuk anak usia 5-6 tahun dan keamanan alat permainan untuk anak seperti tidak berbau menyengat, tidak tajam pada setiap sisi dan tidak licin.

Produk permainan harta karun si bola-bola telah melalui proses validasi dari ahli sosial emosional anak usia dini dengan hasil 87,5\%. Apabila disetarakan dengan kriteria kelayakan permainan maka termasuk dalam persentase $81,00 \%-100,00 \%$ degan kualifikasi sangat layak, atau dapat digunakan tanpa revisi. Ahli kinestetik memberikan beberapa saran dan masukan yaitu: 1) permainan harus memiliki rangkaian yang saling berhubungan antara satu permaianan dengan permainan yang lain sehingga permaianan tersebut terdapat tujuan yang dicapai anak, 2) tingkat kesulitan permainan (puzzle) harus sesuai dengan kriteria anak usia 5-6 tahun, 3) menjadikan permainan yang tidak monoton, 4) menambahkan buku petunjuk.

Peneliti perlu melakukan revisi berdasarkan saran dan masukan ahli sosial emosional agar memenuhi kriteria layak. Revisi yang di lakukan yaitu: 1) peneliti menambahkan cerita agar permainan saling berkesinambungan dan memiliki tujuan di akhir permainan, 2) menambahkan potongan puzzle yang sesuai dengan tingkatan usia yang berjumlah 8 keping dari 6 keping potongan puzzle, 3) peneliti menambahakan permaianan yang bervariatif dengan menambahkan karakter si bolabola yang dibawa anak sampai akhir permainan 4) melengkapi dengan buku petunjuk penggunaan permainan

Berdasarkan data keseluruhan uji coba kelompok kecil terkait aspek keamanan, kemudahan dan kemenarikan diketahui bahwa jumlah skor yang diperoleh persentase hasil sebesar $86,8 \%$. Selaras dengan itu, produk yang diuji coba pada lapangan awal (kelompok kecil) berada pada kriteria persentase sangat layak atau dapat digunakan tanpa revisi karna berada ditingkat angka persentase 81,00\%-100,00\% (sangat layak). Sedangkan uji coba lapangan terkait aspek kemudahan, keamanan, dan kemenarikan diketahui bahwa jumlah skor yang diperoleh persentase hasil sebesar $94,8 \%$. Selaras dengan itu, produk yang diuji coba lapangan berada pada kriteria persentase sangat layak atau dapat digunakan tanpa revisi karna berada ditingkat angka persentase 81,00\%-100,00\% (sangat layak).

\section{SIMPULAN}

Permainan harta karun si bola-bola yang memiliki 6 zona yang aman, mudah dan menarik untuk anak, permainan ini juga bertujuan untuk meningkatkan kecerdasan sosial emosional adapun kemampuan yang ditingkatkan pada permainan adalah sebagai berikut, bermain dengan teman, mematuhi peraturan, bersabar, bekerja sama dan bebagi dengan teman. Proses pengembangan telah melalui beberapa tahap evaluasi. Tahapan evaluasi yang dilalui yaitu evaluasi para ahli, uji kelompok kecil, dan uji lapangan (kelompok besar). Revisi produk yang telah dilakukan didasarkan pada saran para ahli sudah sesuai dengan kriteria pemilihan permainan yang tepat dan aman untuk anak.

Tahap selanjutnya yaitu evaluasi pada uji kelompok kecil dan uji lapangan (kelompok besar) terhadap produk yang direvisi terkait aspek keamanan, kemudahan dan kemenarikan. Hasil persentase skor keseluruhan pada uji kelompok kecil menunjukkan permainan sangat layak, sedangkan pada uji lapangan (kelompok besar) persentase menunjukkan permainan sangat layak . Hal ini menunjukkan bahwa produk dapat digunakan tanpa revisi. Oleh karena itu produk dapat diimplementasikan untuk kegiatan permainan anak dilapangan sebagai penunjang proses bermain. Produk pengembangan 
Rahma Putri Wina, Tomas Iriyanto, Eny Nur Aisyah

permainan harta karun si bola-bola dilakukan dilima lembaga TK dengan sasaran anak yang berusia 56 tahun.

\section{DAFTAR PUSTAKA}

Akbar, S. 2013. Instrumen Perangkat Pembelajaran. Bandung: PT Remaja Rosdakarya. Masgumelar, N.K., dkk. 2017. Pengembangan Permainan Aku dan Hewan Menggunakan Multimedia Interaktif Untuk Guru Anak Usia Dini. Gelanggang Pendidikan Jasmani Indinesia, 1(1). Dari http://karyailmiah.um.ac.id/index.php/Penjaskes/article/view/54574.

Martani, W. (2012). Metode Stimulasi dan Perkembangan Emosi Anak Usia Dini. Jurnal Psikologi. 39(1). 112 - 120. doi: http://www.academia.edu/download/50777567/183-296-1-SM.pdf.

Nurmalitasari, F. (2015). Perkembangan Sosial Emosi pada Anak Usia Prasekolah. Buletin UGM. 23(2). 103 - 111. doi: 10.22146/bpsi.10567

Pramono. 2015. Bermain \& Permainan. Malang: Universitas Negeri Malang.

Santrock, J.W. 2007. Perkembangan Anak (diterjemahkan Wisdyasinta Benedictine). Jakarta: Penerbit Erlangga.

Sudono, A. 2000. Sumber Belajar \& Alat Permainan. Jakarta: PT Gramedia.

Sugiyono. 2016. Metode Penelitian Kuantitatif, Kualitatif, dan R\&D. Bandung: Alfabeta.

Wiyani, Novan Ardy. 2014. Mengelola dan Mengembangkan Kecerdasan Sosial dan Emosi Anak Usia Dini. Jogyakarta: Ar-Ruzz Media. 